\title{
The Effect of an Assembling and Modify Combine Equipment on Some Machinery Unit Indicators and Sunflower Yield*
}

\author{
*Abdulrazzak A. Jasim, Shrook K. Mahde \\ Prof. PhD. Senior.Ag.Eng \\ Dept of Agricultural Machines and Equipment, College of Agriculture, University of Baghdad. \\ *Corresponding Author: Abdulrazzak A. Jasim
}

\begin{abstract}
A field experiment was conducted to evaluate the effectofan assembling and modify combine equipment which used for mechanical and chemical cultivation and spraying fertilizer, on some machinery indicators, some soil properties and Sun flower yield in the College of Agriculture / University of Baghdad field during the spring summer growing season of 2016. Three levels of machinery speed included: 6.8, 4.51and 2.85 $\mathrm{Km} \cdot \mathrm{hr}^{-1}$ and cultivation treatments included: mechanical chemical cultivation and spraying fertilizers, mechanical and chemical cultivation, mechanical and spraying fertilizers and control treatment were studied in this experiment. Field efficiency, soil moisture content, Plant height, plant yield,weed control percentagewere measured in this experiment. Nested designs under randomized complete block design (RCBD) with, three replications were used in this study. Least significant difference at 0.05 probabilities was used to compare the mean of the treatments.
\end{abstract}

The results showed that increasing machinery speed from 2.85 to 4.51 to $6.8 \mathrm{Km} . \mathrm{hr}^{-1}$ led to a significant increase insoil moisture content stood 17.31 to 18.38 to $18.82 \%$, plant height stood 131.26 to 133.03 to 136.88 $\mathrm{cm}$, plant yields stood 7.34 to 8.05 to 8.52 ton.ha ${ }^{-1}$, weed control percentage stood 83.68 to 89.81 to $91.53 \%$. Decreasing machinery speed from 6.8 to 4.51 to $2.85 \mathrm{Km} . \mathrm{hr}^{-1}$ led to a significant increase in field efficiency stood 61.71 to 62.62 to $64.75 \%$.

Mechanical, chemical cultivation and spraying fertilizer treatment was significantly superior on other treatments in soil moisture content, plant height and plant yield. Mechanical and chemical cultivation treatment was significant superior in increasing weed control percentage. There was no significant effect in field efficiency by cultivation treatments.

There were significant differences on the studied properties attributed by the interaction treatments. 6.8 $\mathrm{Km} . \mathrm{hr} \mathrm{r}^{-1}$ and mechanical, chemical cultivation and spraying fertilizer cultivation interaction caused significant increase in soil moisture content stood $18.91 \%$, plant height stood $137.88 \mathrm{~cm}$ and plant yield stood 8.99 ton. $h^{-1} .6 .8 \mathrm{Km} \cdot \mathrm{hr}^{-1}$ and mechanical and chemical cultivation treatment caused significant increase in weed control percentage stood $92.33 \%$. There were no significant differences on field efficiency, due to interferences treatments.

There were significant differences between cultivation treatments and the control treatment. Mechanical chemical cultivation and spraying fertilizer was significant superior in soil moisture content stood $18.25 \%$ on control treatment which got $17.76 \%$, mechanical and chemical cultivation and spraying fertilizer treatment got the best plant height stood $134.58 \mathrm{~cm}$, while control treatment got $127.00 \mathrm{~cm}$,mechanical and chemical cultivation andspraying fertilizer treatment got the best plant yieldsstood 8.54 ton.ha ${ }^{-1}$ while control treatment got 6.68 ton. $\mathrm{ha}^{-1}$, mechanical and chemical cultivation treatment got the best weed control percentage stood $89.44 \%$ while control treatment got $6.66 \%$.

The locally assembled,manufactured and modified combine equipment was successfully used for mechanical chemical cultivation and sprayingfertilizer with high efficiency.

Keywords: Field efficiency, soil moisture content, Plant height, plant yield,weed control percentage.

\section{Introduction}

Combine equipment are a set of equipment that are linked together by a single structure, which is separated from a process for the service of agriculture and within one pass, and may include a set of primary and secondary implements for soil preparation and special implements and crop service equipment (Albanna, 1990).

Cultivationimplements are used to leave soil surface morefragmentation and dismantlingin the fieldso as to increase soil water storage by increasing soil water infiltration and reduce water and wind erosion, and also have the ability to remove the remnants of the weed that compete with crops.There are different set of 
shares that connect to the cultivation, including a double-headed and there are sweep shares used in the heavy soil or in the soil which affected by weeds and mainly in the service of the growing crop.

Kepner,et. al., (1972) pointed that cultivation method which is still equipment method is the best to control weeds. It is basically an economic method can be easily used, for controlling weeds.

Modern agriculture has relied on the use of chemical pesticides and herbicides as the most modern methods of control over agricultural pests and weeds, and they are considered the fastest and most effective in affecting the weed without damagethe crop. The addition of chemical fertilizer to the soil has a positive effect on improving the properties of physical and chemical soil so that the soil becomes more fertile. Chemical fertilizers contain all the nutrients necessary for the growth and development of the plant (Al-Quraguli and Jasim, 2012, and Hassan et.al., 1990).

Sun flower is one of the most important oily industrial crops. It belongs to the composite family. It is ranked the third after soybean and corn in the world of oil production. Sunflower oil is one of the best vegetable oils consumed globally, (Alahadadi, et. Al., 2011, andBakhat, et. al., 2010).

Because of the importance of using a combine equipment to serve the growing crop and to study its impact on the growth and production of sun flower, this study was conducted.

\section{Materials and Methods}

Field experiments was conducted with the aim of studying assembling and modify a combine equipment used for mechanical and chemicalcultivation and fertilizer spraying, and its effect on some machinery indicators, some soil properties and sun flower yield in the College of Agriculture / University of Baghdad field during summer growing season of 2016. Three levels of machinery speed included: 6.8, 4.51 and 2.85 Km.hr ${ }^{-1}$ and cultivation treatments included: mechanical chemical cultivation and fertilizer spraying, mechanical and chemical cultivation, mechanical and fertilizer spraying and control treatment were studied in this experiment. Field efficiency, soil moisture content, Plant height, plant yield, weed control percentage were measured in this experiment. Nested design under randomized, complete block design (RCBD) with, three replications was used in this study. Least significant difference at 0.05 probabilities was used to compare the mean of the treatments. Soil Physicaland chemical properties were shown in table (1).

Table 1. Physical and chemical soil properties.

\begin{tabular}{|c|c|c|c|c|c|c|c|}
\hline \multirow{2}{*}{$\underset{\text { Mg.kg-1 }}{K}$} & \multirow{2}{*}{$\underset{\text { Mg.kg-1 }}{\mathbf{P}}$} & \multirow{2}{*}{ PH } & \multirow{2}{*}{$\begin{array}{c}\text { EC } \\
\text { ds.m }\end{array}$} & \multicolumn{3}{|c|}{$\begin{array}{c}\text { Volumetric distribution of soil separators } \\
\text { gm.kg } \square 1\end{array}$} & \multirow{2}{*}{ Soil tissue } \\
\hline & & & & Gland tissue & Clay tissue & Sand tissue & \\
\hline 91.04 & 31.99 & 7.35 & 1.2 & 393 & 168 & 438 & Loam \\
\hline
\end{tabular}

The cultivation depth was $10 \mathrm{~cm}$.Spraying fertilization and herbicide was at aheight of $10 \mathrm{~cm}$ above soil surface. Planting sunflower seeds was at 14/8/2016 with $75 \mathrm{~cm}$ distance between planting lines and $20 \mathrm{~cm}$ between plants. Harvest date was at 21/11/2016.

Combine equipment was manufactured and assembled at the department of agricultural machines and equipment workshop, College of Agriculture, University of Baghdad. The combine equipment consists of three implements included cultivation mechanical, chemical and spraying fertilizer, which achieve the three operations at once, figure 1 and 2 .

\subsection{Components of the combine equipment:}

The combine equipment consists of three main equipment as follows:

A- Spring cultivator with double sweep shares implement

B- Herbicide sprayer equipment

C- Fertilizersprayer equipment 


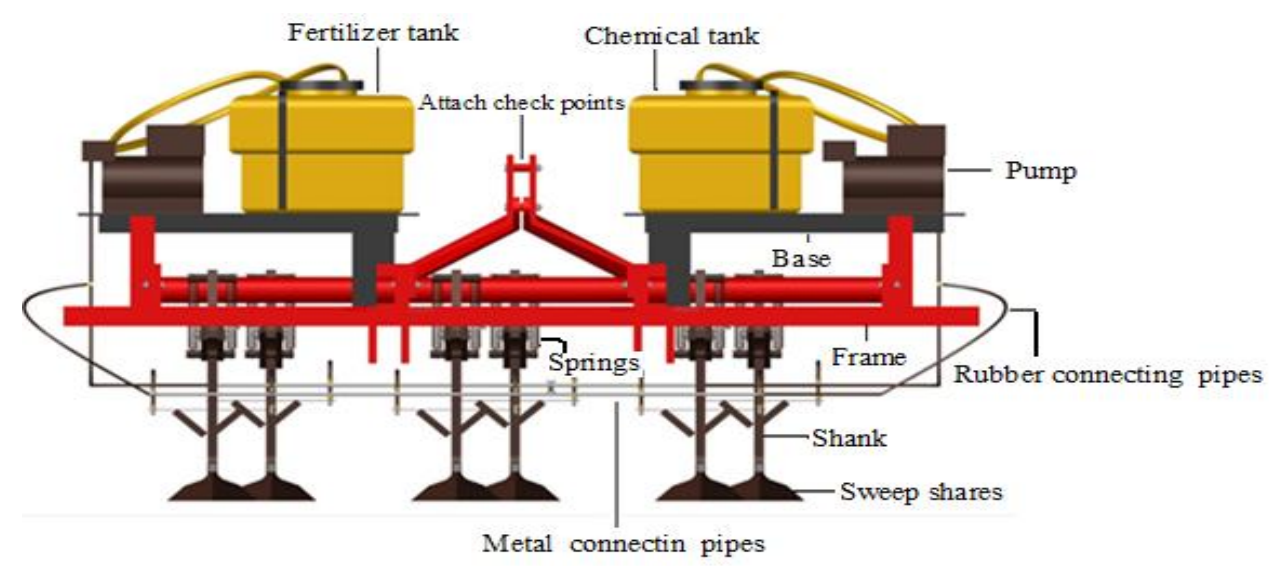

Figure 1. Combine implement parts.

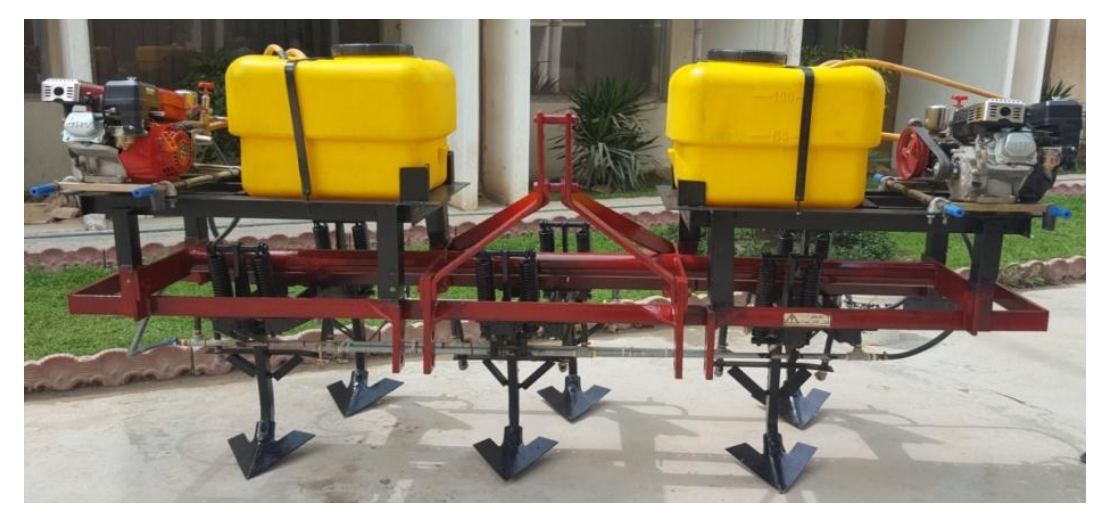

Figure 2. Combine implement picture.

\section{2 - Studied Indicators}

\subsection{1- Field efficiency $(\%)$ :}

Fieldefficiency was measured using the following equation whichproposed byBuckingham,et. al., (1979):

Whereas:

$$
\boldsymbol{F} \boldsymbol{e} \%=\frac{\boldsymbol{P p}}{\boldsymbol{P t}} \times 100
$$
$\mathrm{Fe}=$ Field efficiency $(\%)$
$\mathrm{Pp}=$ Practical productivity $\left(\right.$ ha. $\left.\mathrm{hr}^{-1}\right)$
$\mathrm{Pt}=$ Theoretical productivity $\left(\right.$ ha. $\left.^{-1} \mathrm{r}^{-1}\right)$

\subsection{2- Soilmoisture content $(\%)$ :}

Soil moisture content was measured using the following equation which proposed byGardner ,(1965):

Whereas:

$$
M c=\frac{M s w-M s}{M S} \times 100
$$
Ms= Soilmoisture content $(\%)$
Msw $=$ Mass of moist soil $(\mathrm{gm})$
Ms= Mass of dry soil (gm)

\subsection{3- Plant height $(\mathrm{cm})$ :}

The height of the plant was measured from the surface of the soil up to the disk base of five randomly selected plants from the middle lines. The average height of the plant was extracted according to the method which proposed byElsahooke,(1990).

\subsection{4- Plant yield (ton.ha $\square$ ):}

It was calculated from the mean of five randomly selected plants from the median lines of each experimental unit and multiplied by plant density(Elsahooke ,1990).

\subsection{5- Weedcontrol percentage $(\%)$ :}

Weed control percentage were measured after 30 and 60 days. Density of weeds was estimated by calculating the number of weeds per square meter from the center of each experimental unitusing the following equation which proposed by Ciba-Giegy ,(1975): 
Whereas:

$$
W . C=\frac{A-B}{A} \times 100
$$

$\mathrm{W} . \mathrm{C}=$ weed control percentage were measured $(\%)$

$A=$ Number of weed in the in treatment

$B=$ Number of weed in the in control treatment

\subsection{Field Efficiency $(\%)$ :}

\section{Results and Discussion}

Table (2) shows the effect of the machinery unit speed on field efficiency. The results indicate that increasing in machinery unit speed from 2.85 to 4.51 to $6.8 \mathrm{~km} \cdot \mathrm{hr}^{-1}$ led to a significant increase in field efficiency stood 61.71 to 62.62 to $64.75 \%$,that happened because of increasing in machinery unit speed was caused increasing in operation width, and practical productivity and decreasing time using factor which led to decrease in field efficiency and these results are consistent with the results obtained by Alhadithi and Albadri ,(2012).

Table (2) shows that there is no significant effect between the cultivation treatments on the field efficiency.

Table (2) also shows that there was no significant effect in the interactions between machinery unit speed and cultivation treatments on field efficiency.

Table 2.Effect of machinery unit speed and cultivation treatments and their overlap in field efficiency (\%).

\begin{tabular}{|c|c|c|c|c|}
\hline \multirow{2}{*}{ Average speed } & \multicolumn{4}{|c|}{ Fieldefficiency (\%) } \\
\cline { 2 - 5 } & $\begin{array}{c}\text { Mechanical cultivation } \\
\text { and spraying fertilizer }\end{array}$ & $\begin{array}{c}\text { Mechanical and } \\
\text { chemical cultivation }\end{array}$ & $\begin{array}{c}\text { Mechanical and } \\
\text { chemical cultivation } \\
\text { and spraying fertilizer }\end{array}$ & \multirow{2}{*}{ Speed } \\
\hline 61.71 & 61.69 & 61.72 & 61.71 & 6.8 \\
\hline 62.62 & 62.61 & 62.61 & 62.63 & 4.51 \\
\hline 64.75 & 64.74 & 64.76 & 64.76 & 2.85 \\
\hline 0.069 & & N.S & 63.03 & Average treatments \\
\hline & 63.01 & \multicolumn{2}{|c|}{63.03} & LSD \\
\hline
\end{tabular}

\subsection{Soilmoisture content $(\%)$ :}

Table (3) shows the effect of the machinery unit speed on soilmoisture content,the results indicate that increasing in machinery unit speed from 2.85 to 4.51 to $6.8 \mathrm{~km}^{-\mathrm{hr}^{-1}}$ led to a significant increase in soil moisture content stood 17.31 to 18.38 to $18.82 \%$,this may be due to the fact that increasing the speed helps to increase soil size distribution and increase soil fragmentation and dismantling which caused increase infiltration, this results agreedwith the results obtained by Aljanabi, (2000).

Table (3) shows that there is significant effect between the cultivation treatments on the soil moisture content. Mechanical, chemical cultivation and fertilizer spraying treatment was significantly superior on mechanical and chemical treatment and mechanical and fertilizer spraying treatment in soil moisture content.

Table (3) also shows that there was significant effect in the interactions between machinery unit speed and cultivation treatments on soil moisture content. $6.8 \mathrm{Km}_{\mathrm{hr}}{ }^{-1}$ and mechanical, chemical cultivation and spraying fertilizer interaction caused significant increase in soil moisture content stood $18.91 \%$.

There was a significant differencebetween cultivation treatments and the control treatment. Mechanical, chemical cultivation and spraying fertilizer was significant superior in soil moisture content stood $18.25 \%$ on control treatment which got $17.76 \%$. 
Table 3. Effect of machinery unit speed and cultivation treatments and their overlap in soil moisture content $(\%)$.

\begin{tabular}{|c|c|c|c|c|}
\hline \multicolumn{5}{|c|}{ Soil moisture content $(\%)$} \\
\hline \multirow[b]{2}{*}{$\begin{array}{l}\text { Average } \\
\text { speed }\end{array}$} & \multicolumn{3}{|c|}{ Cultivation treatments } & \multirow[b]{2}{*}{ Speed } \\
\hline & $\begin{array}{c}\text { Mechanical } \\
\text { cultivation and } \\
\text { spraying fertilizer }\end{array}$ & $\begin{array}{c}\text { Mechanical and } \\
\text { chemical cultivation }\end{array}$ & $\begin{array}{c}\text { Mechanical and chemical } \\
\text { cultivation and spraying } \\
\text { fertilizer }\end{array}$ & \\
\hline 18.82 & 18.81 & 18.75 & 18.91 & 6.8 \\
\hline 18.38 & 18.34 & 18.30 & 18.52 & 4.51 \\
\hline 17.31 & $\mathbf{1 7 . 3 0}$ & 17.31 & 17.34 & 2.85 \\
\hline \multirow[t]{5}{*}{0.058} & \multicolumn{3}{|c|}{0.078} & LSD \\
\hline & 18.15 & \multicolumn{2}{|c|}{18.12} & Average treatments \\
\hline & \multicolumn{3}{|c|}{0.043} & LSD \\
\hline & \multicolumn{3}{|c|}{$\mathbf{1 7 . 7 6}$} & Control treatment \\
\hline & \multicolumn{3}{|c|}{0.076} & LSD \\
\hline
\end{tabular}

\subsection{Plant height (cm):}

Table (4) shows the effect of the machinery unit speed on plant height,the results indicate that increasemachinery unit speed from 2.85 to 4.51 to $6.8 \mathrm{~km} \cdot \mathrm{hr}^{-1}$ led to a significant increase in plant height stood from 131.26 to 133.03 to $136.88 \mathrm{~cm}$. This may be due to the increase in machinery unit speed, led to increase working widthsoil size distributionand soilventilation which is necessary to breathe roots to carry out its vital functions and therefore increase the height of plant and this results agreed with the results obtained by Abdul Ali, (2013).

Table (4) shows that there is significant effect between the cultivation treatments on plant height.Mechanical, chemical cultivation and spraying fertilizer treatment was significantly superior on mechanical and chemical treatment and mechanical and spraying fertilizer treatment inplant height.

Table (4) shows that there was significant effect of the interactions between machinery unit speed and cultivation treatments on plant height.6.8 $\mathrm{Km}_{\mathrm{hr}}{ }^{-1}$ and mechanical, chemical cultivation and spraying fertilizer interaction caused significant increase in plant height stood $137.88 \mathrm{~cm}$.

There are significant differencesbetween cultivation treatments and the control treatment. Mechanical, chemical cultivation and spraying fertilizer was significant superior in plant height stood $134.58 \mathrm{~cm}$, while control treatment got $127.00 \mathrm{~cm}$.

Table 4.Effect of machinery unit speed and cultivation treatments and their overlap in Plant height $(\mathrm{cm})$.

\begin{tabular}{|c|c|c|c|c|c|}
\hline \multicolumn{6}{|c|}{ Plant height $(\mathrm{cm})$} \\
\hline \multirow[b]{2}{*}{$\begin{array}{l}\text { Average } \\
\text { speed }\end{array}$} & \multicolumn{4}{|c|}{ Cultivation treatments } & \multirow[b]{2}{*}{ Speed } \\
\hline & $\begin{array}{c}\text { Mechanical } \\
\text { cultivation and } \\
\text { spraying fertilizer }\end{array}$ & $\begin{array}{l}\text { Mechanical and } \\
\text { chemical cultivation }\end{array}$ & \multicolumn{2}{|c|}{$\begin{array}{c}\text { Mechanical and chemical } \\
\text { cultivation and spraying } \\
\text { fertilizer }\end{array}$} & \\
\hline 136.87 & 135.87 & 136.87 & \multicolumn{2}{|c|}{137.88} & 6.8 \\
\hline 133.03 & 133.13 & 132.07 & \multicolumn{2}{|c|}{133.89} & 4.51 \\
\hline 131.26 & 131.47 & 130.33 & \multirow{2}{*}{\multicolumn{2}{|c|}{131.98}} & 2.85 \\
\hline \multirow[t]{5}{*}{1.466} & \multicolumn{2}{|r|}{2.24} & & & LSD \\
\hline & \multicolumn{2}{|c|}{133.49} & 133.09 & 134.58 & Average treatments \\
\hline & \multicolumn{4}{|c|}{3.35} & LSD \\
\hline & \multicolumn{4}{|c|}{127.00} & Control treatment \\
\hline & \multicolumn{4}{|c|}{3.715} & LSD \\
\hline
\end{tabular}

\subsection{Plant yield (ton.ha $\square$ ):}

Table (5) shows the effect of the machinery unit speed on plant yield.The results indicate that increasemachinery unit speed from 2.85 to 4.51 to $6.8 \mathrm{~km} \cdot \mathrm{hr}^{-1}$ led to a significant increase in plant yield stood 7.34 to 8.05 to 8.52 ton.ha ${ }^{-1}$. This may be due to the increase in machinery unit speed, caused increase plant height and other growth characteristics of the plant of the sunflower,therefore increase the yield of plant and this results agreed with the results obtained by Abdul Ali, (2013).

Table (5) shows that there is significant effect between the cultivation treatments on plant yield.Mechanical, chemical cultivation and spraying fertilizer treatment was significantly superior on mechanical and chemical treatment and mechanical and spraying fertilizer treatment in plant yield.

Table (5) shows that there is significant effect of the interactions between machinery unit speed and cultivation treatments on plant yield. $6.8 \mathrm{Km} \cdot \mathrm{hr}^{-1}$ and mechanical, chemical cultivation and spraying fertilizer interaction caused significant increase in plant yield stood 8.99 ton. ha ${ }^{-1}$. 
There are significant differencesbetween cultivation treatments and the control treatment. Mechanical, chemical cultivation and spraying fertilizer was significant superior in plant yieldsstood 8.54 ton.ha $^{-1}$ while control treatment got 6.68 ton.ha ${ }^{-1}$.

Table 5. Effect of machinery unit speed and cultivation treatments and their overlap in Plant yield (ton.ha ${ }^{-1}$ ).

\begin{tabular}{|c|c|c|c|c|}
\hline \multicolumn{5}{|c|}{ Plant yield (ton.ha $\square$ ) } \\
\hline \multirow[b]{2}{*}{ Average speed } & \multicolumn{3}{|c|}{ cultivation treatments } & \multirow[b]{2}{*}{ Speed } \\
\hline & $\begin{array}{l}\text { Mechanical cultivation } \\
\text { and spraying fertilizer }\end{array}$ & $\begin{array}{c}\text { Mechanical and } \\
\text { chemical cultivation }\end{array}$ & $\begin{array}{c}\text { Mechanical and } \\
\text { chemical cultivation } \\
\text { and spraying } \\
\text { fertilizer }\end{array}$ & \\
\hline 8.52 & 8.36 & 8.23 & 8.99 & 6.8 \\
\hline 8.05 & 7.80 & 7.49 & 8.87 & 4.51 \\
\hline 7.34 & 7.18 & 7.09 & 7.76 & 2.85 \\
\hline \multirow[t]{5}{*}{0.17} & \multicolumn{3}{|c|}{0.2533} & LSD \\
\hline & 7.78 & 7.60 & 8.54 & Average treatments \\
\hline & \multicolumn{3}{|c|}{0.1518} & LSD \\
\hline & \multicolumn{3}{|c|}{6.68} & Control treatment \\
\hline & \multicolumn{3}{|c|}{0.2432} & LSD \\
\hline
\end{tabular}

\subsection{Weed control percentage $(\%)$ :}

Table (6) shows the effect of the machinery unit speed on weed control percentage, the results indicate that increase in machinery unit speed from 2.85 to 4.51 to $6.8 \mathrm{~km} \cdot \mathrm{hr}^{-1}$ led to a significant increase in weed control percentage stood 83.68 to 89.81 to $91.53 \%$, this may be due to that increase in the machinery unit speed, caused increase working width of the spraying area of the herbicide and more soil morefragmentation and dismantling whichincrease weed control percentage, this results are agreedwith the results obtained by Alqurguli, (2011).

Table (6) shows that there is significant effect of cultivation treatments onweed control percentage.Mechanical, chemical cultivation and spraying fertilizer treatment was significantly superior on Mechanical and chemical cultivation treatment was significant superior in increasing weed control percentage.

Table (6) shows that there is significant effect of the interactions between machinery unit speed and cultivation treatments onweed control percentage. $6.8 \mathrm{Km} \cdot \mathrm{hr}^{-1}$ and mechanical and chemical cultivation treatment caused significant increase in weed control percentage stood $92.33 \%$.

There are significant differencesbetween cultivation treatments and the control treatment. Mechanical and chemical cultivation treatment got the best weed control percentage stood $89.44 \%$ while control treatment got $6.66 \%$.

Table 6. Effect of machinery unit speed and cultivation treatments and their overlap in weed control percentage $(\%)$.

\begin{tabular}{|c|c|c|c|c|}
\hline \multicolumn{5}{|c|}{ Weed control percentage $(\%)$} \\
\hline \multirow[b]{2}{*}{ Average speed } & \multicolumn{3}{|c|}{ Cultivation treatments } & \multirow[b]{2}{*}{ Speed } \\
\hline & $\begin{array}{c}\text { mechanical } \\
\text { cultivation and } \\
\text { spraying fertilizer }\end{array}$ & $\begin{array}{c}\text { mechanical and } \\
\text { chemical cultivation }\end{array}$ & $\begin{array}{l}\text { Mechanical and chemical } \\
\text { cultivation and spraying } \\
\text { fertilizer }\end{array}$ & \\
\hline 91.53 & 90.61 & 92.33 & 91.67 & 6.8 \\
\hline 89.81 & 89.22 & 90.67 & 89.56 & 4.51 \\
\hline 83.68 & 82.00 & 85.33 & 83.71 & 2.85 \\
\hline \multirow[t]{5}{*}{0.136} & \multicolumn{3}{|c|}{0.1882} & LSD \\
\hline & 87.27 & 89.44 & 88.31 & Average treatments \\
\hline & \multicolumn{3}{|c|}{0.1080} & LSD \\
\hline & \multicolumn{3}{|c|}{6.66} & Control treatment \\
\hline & \multicolumn{3}{|c|}{0.07329} & LSD \\
\hline
\end{tabular}

\subsection{Conclusions}

1- Increasing machinery speed led to a significant increase soil moisture content, plant height, plant yields, and weed control percentage. Decreasing machinery speed led to a significant increase in field efficiency.

2- Mechanical, chemical cultivation and spraying fertilizer treatment was significantly superior on mechanical and chemical treatment and mechanical and spraying fertilizer treatment in soil moisture content, plant height and plant yield. Mechanical and chemical cultivation treatment was significant superior in increasing weed control percentage. There is no significant effect on field efficiency attributedby cultivation treatments. 
3- There are significant differences between cultivation treatment and the control treatment. Mechanical, chemical cultivation and spraying fertilizer was significant superior in soil moisture content on control treatment, plant height, plant yields, mechanical and chemical cultivation treatment got the best weed control percentage with control treatment.

\subsection{Recommendations}

1- Using thecombine equipment for cultivation is recommendedbecause itgives the best results.

2- Further studies to be carried out on the use of locally combine equipment in different soil, crops and other conditions, as well as on different land plots and spraying of herbicides with different depths are recommended.

[1]. Abdul Ali,k,M., (2013) . Effect of type plow depth plowing and speed different in some technical indicators of the mechanized unit and Growth and sun flower. .Journal of the Euphrates Agricultural Sci- 5(3): 288-302.

[2]. Alahadadi, I. ; H. Oraki and F. P. Khajani , (2011). Effect of water stress on yield and yield components of sunflower hybrids. African J. of Biotic.10 (34):6504-6509.

[3]. Albanna, A.R.., (1990). Soil preparation equipmemt. Ministry of Higher Education and Scientific Research. University of AlMosul.

[4]. Al-Hadithi,H, and Samer,B,Al-Badri., (2012). Determination of the efficicency of the performance of the drill plow and the spsing chemical cultivation.Journal of Iraqi Agricultural Sci - 43(4): 93-101.

[5]. Al-Janabi,O.R.,(2000). Performance of tractor MF-399 four-wheel drive with four-disc plow and its overlap with some phsical properties of the soil, Master thesis, college of agriculture, University of Baghdad,Iraq.

[6]. Al-Quraguli, O. K., and A. A. Jasim, (2012). A comparative the performance for different plows on inject traflan herbicide under soil surface. Technical Journal Vol. 25. No. 2, pp: 22. Tec. Educ. Foundation. Baghdad, Iraq.

[7]. Al-Qurguli,O,k,Hassen., (2011). Comparison of the performance of different plows in infusion of turflene under the soil surface, Master thesis, college of agriculture, University of Baghdad,Iraq.

[8]. Bakhat ,J. ; M. Shafi ; M. Yousaf ; L. Raziuddin ; and M. Khan,(2010). Effect of irrigation on physiology and yield of Sunflower hybrids. Pak. J. Bot., 42 (2) : 1317-1326.

[9]. Buckingham, F;Thorngren,. and B. Johannes, (1976). Fundamentals of machine operation: tillage. John deers service publication. moline, IL. Athorough nuts-and-bolts treatment of tillage machinery.

[10]. Hassan,N,H.,andHassan,E,Al- Dulaimi., and Latef,A,A,Al-Aythawi., (1990).Soil fertility and fertilizers, Ministry of Higher Education and Scientific Research. University of Baghdad,Iraq.

[11]. El-Sahooke, (1990). Application in experiment design and analysis. University of Baghdad, Ministry of higher Education an Scientific Resarches, Iraq.

[12]. Gardner, W. H., (1965). Water content in: Black, C. A (eds). Method of soil analysis-part. Agro. No. 9:82-127.

[13]. Grisso, R. D; J. Perumpral; D. Vaughan; G. T. Roberson and R. Pitman, (2010). Predicting tractor diesel fuel consumption .virginia cooperative extension. PUBLICATION 442-073.

[14]. Kepner, R. A; Roy Bainer and E. L. Barger, (1972). Principles of farm machinery. The AVI Publishing company, INC. U. S. A.

Abdulrazzak A. Jasim. "The Effect of an Assembling and Modify Combine Equipment on Some Machinery Unit Indicators and Sunflower Yield*." IOSR Journal of Agriculture and Veterinary Science (IOSR-JAVS) 10.7 (2017): 64-70. 